\title{
COVID-19 an Unprecedented Pandemic; Government palliative: Nigerians experience.
}

\author{
Nweze, Chiamaka Nneoma
}

Faculty of Education, Department of Education, Leadership, and Management Southwest University, Chongqing 400715, China

\begin{abstract}
Research on the Pandemic is worth carrying due to the risk and ongoing risk; the COVID-19virus, which was first detected at the end of 2019, has caused countries across to Globe to either shut down entirely or partially, therefore, unprecedently affected people's daily life and has also intensified my worry on how Nigerians will survive due to its implication. In recognizing the dilemma associated, the Global financial institutes, Governments, and private individuals of different countries provided palliative materials. The study was aims to determine what aspect of one's life was affected the most and how was the palliative material provided by the Government distributed in Awka, Anambra State. The study adopted a quantitative means of data collection among a sample 120participants.Random sampling techniques was used to select the respondents. Data obtained were conceptually analyzed using Statistical Package for Social Science(SPSS). A key result from the finding reveals that finance was the aspect affected mostly, and that government palliative was not effectively distributed as some were being hoarded and hijacked. It is also recommended in face of any pandemics that the vulnerable, the poor and the informal workers should be considered first, because they are usually the one affected first.
\end{abstract}

Keywords: Coronavirus, Impact, Palliative, Nigeria;

\section{Introduction}

In the history of humankind, there have been different diverse plagues that have impacted the social, health, economic and financial sectors resulting in millions of deaths such as The Black Death "Plague Outbreak" that have killed 75-100million people between 1347 and 1351; The Bleeding Fever epidemic between 1899 and 1923(Zeren, \& Hizarci,2020); Ebola (EVD) 2014-2016 described as "Black Swan" by (Brown, Ark ell, \& Rokadiya.2014; p45:2-5); AIDS virus that first appeared in Cameroon; The Cholera epidemic in 1908 Mexico; The SARS in Asia and Canada; H5N1; Zika; the Spanish flu of 1918-1919 which 
was caused by HINI from January 1918 to December 1920 making it the deadliest Pandemic in history as affected over 500million people, and killed 50 to 100million people); Swine Flu, 2009-2010; SARS,20022003; MERS-CoV,H1N1(Sa \&Serpa,2020;Zeren \&Hizarci,2020).Currently, the world is experiencing a similar pandemic caused by the SARS-CoV-2 virus(WHO,2020f).

COVID-19Coronavirus(2019-nCoV) is a new viral disease that first appeared in Wuhan City, Hubei Province, China (Estrada et al.,2020; Huang et al.,2020; WHO,2020a). Coronaviruses are non-segmented positive-sense RNA viruses that belong to the family of Coronaviridae and its order Nidovirales. But, it primarily can be transmitted from human to human and it's the first time throughout history this type of transmission (Huang, Chaolin, et al.,2019; Haleem, Javaid, \& Vaishya,2020). Empirical research indicated that the virus originated from a seafood wholesale market in Wuhan Hubei province China (Chan et al.,2020; McKibin \&Fernando,2020). The Chinese Center for Disease Control and Prevention(CDC) ruled out likely causes of COVID-19(World Health Organization[WHO],2020e). But, only a few days later, in December 2019, Chinese Government officials identified the actual cause of the virus which was tentatively named 2019 novel coronavirus (2019-nCoV) (Koshle, Kaur, \& Basista, 2020; Chan et al.,2020; Zhou et al.,2020).

And Since the first death of a Chinese national in early January 2020, travel-related cases began emerging in different countries, with the first case of the virus outside Wuhan, China, detected in Thailand on January 13, 2020(WHO. Novel Coronavirus-Thailand,2020), Japan on January 17 (WHO. Novel Coronavirus-Japan,2020), South Korea and the USA on January 21 (WHO. Novel Coronavirus-Republic of Korea,2020; WHO. Novel coronavirus-UnitedStates,2020). COVID-19which started like a "supply shock" has just morphed into an unprecedented economics (Cassidy,2020). However, on January 30, 2020, the outbreak was officially declared a public health emergency with the highest rate of infection, fastest spread across the globe and most difficult to prevent and control (WHO,2020c; ChinaXinhuanet,2020). Thus, on February 11, 2020, the International Committee on Taxonomy of Viruses announces the name of the new virus as "severe acute respiratory syndrome coronavirus2(SARS-CoV-1)" (WHO,2020e). On February 14, 2020, African's first case was detected in Egypt (Gilbert et al.,2020), then followed Nigeria on February,27,2020(Nigeria Center for Disease Control [NCDC],2020a), and this marked the beginning of the COVID-19outbreak in Nigeria. COVID-19 was on March 11, 2020, declared a full-blown pandemic after it has affected over114countries (CDC,2020a; WHO,2020g; Riou \& Althaus,2020; Ojogiwa, \& Akinola,2020), and on March 24, 2020, it already spread across 169 countries with 387,382 cases and 16,767 deaths (John Hopkins University,2020).

Pandemic has been seen as a roadblock by many(CODE,2020) as it has changed economies and societies (Lovelance,2020; Haleem, Javaid, \&Vaishya,2020) and people's daily lives (Elavarasan et al.,2020). The term "Pandemic" has not been well defined by different medical texts. Still, it has some key 
characteristics such as diseases movement, novelty, severity, and high attack rates (Qiu, Rutherford, Mao, 2017). Pandemic is used when viruses "can affect people quickly and also spread from one person to another in an efficient and sustained way(CDC,2020). In terms of biological characteristics, the COVID-19Pandemic bears the exact striking resemblance with the 1918 influenza. Both are respiratory diseases that can be transmitted through contact and droplet of an infected person; their preventive measures and health response are also the same in terms of quarantine, isolation, proper hygiene (Salisu, Sikiru \&Vo,2020). The most common symptoms of COVID-19 are Fever, cough, cold, pains, sputum and breathing problem which in turn leads to pneumonia (Chen, et al.,2020a).

According to WHO, preventive measures used in containing the COVID-19 Pandemic depend on each country's ability to control the spread(WHO,2020d). However, some of these measures includes heightened surveillance, tracing of contact person, and quick identification of suspected cases (Gilbert et al.,2020) the researchers also affirms that, a country health care system is primarily a means of managing and controlling the spread of the virus. But before COVID-19pandemic most African countries has been facing challenges of poverty, diseases (Ataguba,2020 p325), inadequate laboratory equipment's, insufficient public health human resource deteriorated health care making it difficult in combating the virus (Ozili,2020; Nkengasong, \&Mankula,2020). As Nigerians number of infected cases continues to rise, Nigerians have also felt the crippling effect of the Pandemic. The government swiftly responded with these measures such as cessation of movement in almost all the states in the country, self-isolation which includes: travel restriction; shutdown of all public gatherings; closure of schools (Oruonye, \& Ahmed,2020), and social distancing, which has now become the buzzword in media(Yan,2020).COVID -19 responses strategies by the Nigerian government.

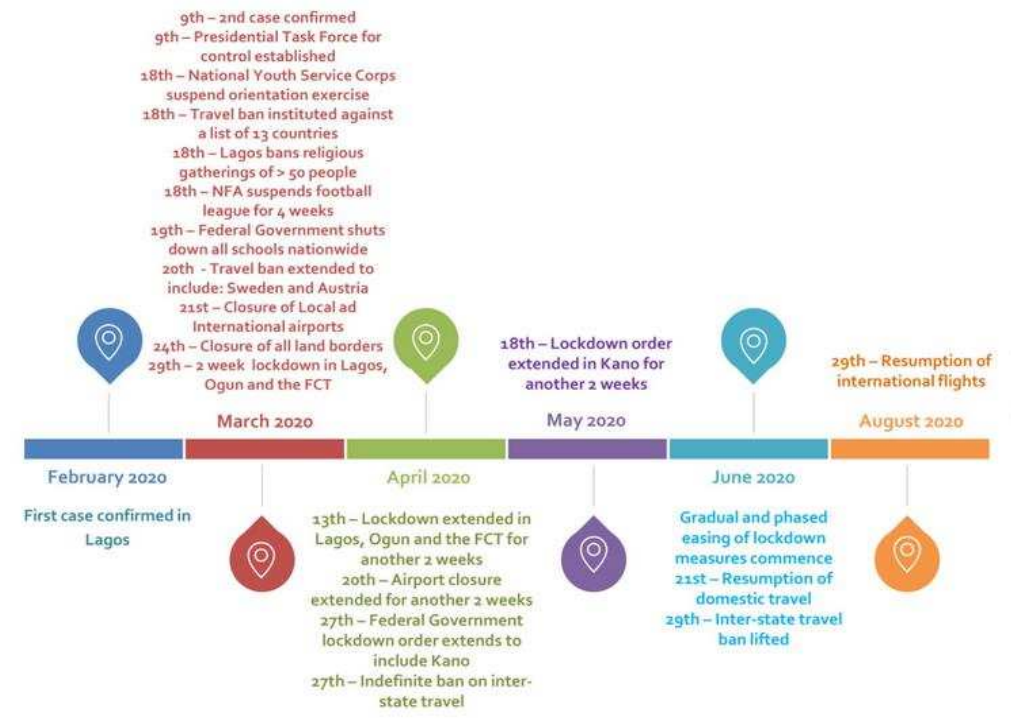

Fig 1: COVID -19 responses strategies employed by the Nigerian Government from Feburary,2020 to August,2020

Source: Adesanya, (2020) 
All these regulations have not gone well with citizens who agitate that it is possible to obey lockdown, but we are hungry, have no food, light, and expect us to stay inside(Peter,2020). This research emphasizes the palliative materials distributed during the COVID-19lockdown in Awka, Anambra State, Nigeria. The majority of Coronavirus literature has focused on the impact of the virus on healthcare (Ather et al.,2020); Economy and stock markets (Fernandes,2020, Ozili and Arun,2020). However, only a few pieces of literature have looked at how palliative material was distributed, in Lagos but none have specifically examined Anambra State, Nigeria. This research aims to find out (a) the aspect of individual life affected the most and(b) who benefited from the government palliative. In this context, answers will be sought to these research questions.

1. What aspect was affected the most during this lockdown?

2. Was palliative distributed? If yes, what's source?

3. What kind of preventive measures were taken to protect oneself?

The finding of the paper reveals that $10.4 \%(\mathrm{n}=10)$ who got palliative got from the "Church and NGO," $7.3 \%(n=7)$ got palliative from the "government," the finding further reveals that Government palliative care was being hoarded and hijacked by officials. The rest of the work is structures as follows. Section 2 presents palliative and measures. Section 3 literature review. Section 4 research methodology. section5discussion of the findings and conclusion.

\section{Palliatives Measures}

Palliative care is a method that improves the quality of life of patients and families who are dealing with physical, psychological, and spiritual problems (WHO,2019).and are also essential in alleviating suffering in other to ensure patients unlikely to survive (Essomba, Ciaffi, Etoundi, \& Esiene, 2020). The outbreak of COVID-19has brought out a critical challenge to different countries' governments and to cushion the effect of the pandemic countries and financial institutions globally responded by providing other stimulus packages and palliative measures (Topcu \&Gulal,2020). Nevertheless, the lockdown by the government has brought or provided reasonable respite for the citizenry, especially those who depend on daily earning for a living(Tacoli,2020). As a way of cushioning the effect of the virus and lockdown, the Nigeria government moves fast to mobilize some materials to respond to the outbreak, which include: a three months' interest holidays for those holding Trademoni, Marketmoni, and Farmermoni loan which is issued by the Bank of Industry, Bank of Agriculture and Nigeria Export and Import. (The Guardian News Paper Report, August 8,2020a). Traders Moni Are loans the Federal Government gives, especially for traders and artisans. It's also a part of the Government Enterprise and Empowerment Program(GEEP) scheme executed by the 
bank. Market Moni: It is a social intervention program that the federal government gives free interest loans to market women, traders, artisans, youth, and farmers. Farm Moni: It is a collateral-free loan design to help petty traders expand their trade and repayable for six months (Eranga, 2020). The Nigeria government, private companies, Non-governmental organizations, and civil society also responded to COVID-19 by providing food items, COVID-19health kits, conditional cash transfers to the poor and vulnerable citizens (Abara,2020; Kalu,2020; CNBC Africa News Report, April 13, 2020). The Central Bank of Nigeria rolled out economic stimulus and fiscal policy measures.

\subsection{Economic stimulus measures:}

a. Interest rate reduction on loan from 9percent to 5percent.

b. Adaptation of a unified exchange rate system by the CBN for interbank and parallels market rates in other to ease pressure on forex earning.

c. We are adopting the official rate of NGN360 to one dollar for international money transfers.

d. We are granting regular forbearance to the bank to restructure terms of facilities in affected sectors.

\subsection{The Fiscal policy measures:}

a. Launching of the COVID-19stimulus to support the economy.

b. Large federal stimulus package for sectors and industries that are highly affected by the COVID-19Pandemic.

c. Increasing indirect spending NGN 3.5 th that is $2.3 \%$ of GDP.

d. Pumping of NGN1.1 trillion (USD3billion) into the critical sector of the economy.

e. Reduction of crude oil benchmark price from USD57 to USD30.

Source: Media report and Central Bank's press release

\section{Government Palliative distribution}

However, it is unclear how successful these interventions /measures are and how long their effect will continue. In some states, the consequences of palliative distribution are based on survival indigenes who engage in wealth development through tax payment The Nigerian Guardian Newspaper Report, April 17, 2020b). The federal government promised palliative measures in the form of conditional cash transfer for about 3.6million vulnerable citizens: however, the eligibility criteria for this measure, which includes community leader's referral and bank balance less than US\$13.the combination of all this rendered this scheme largely ineffective, caused a violation of the human right and 
lockdown directive(Adesanaya,2020). According to a Nigeria newspaper report (Business Day on April 19, 2020).” lamentation still trails Lagos, FG'S palliative package as middlemen hijack program. It is a lamentation and bitter wailing in Lagos, and another part of the country as Nigerians complains that the stimulus package announced by the federal government is being politicized". It could be recounted that the federal government had earlier stated that the palliatives are meant for the vulnerable, and the question now is "who are vulnerable in the society." Bankert \& Amdur (2006) Vulnerability means susceptibility to harm. Palliatives meant for the vulnerable were being shared or hijacked by politicians (Eranga,2020; Business Day Report April,19,2020); not fairly distributed to the targeted population and has caused violence and threatens to protests in different states if the Federal Government of Nigeria extends its Analyst allege corruption in the distribution of palliative all these resulting to the violation of COVID-19lockdownBusiness see (Figure2)

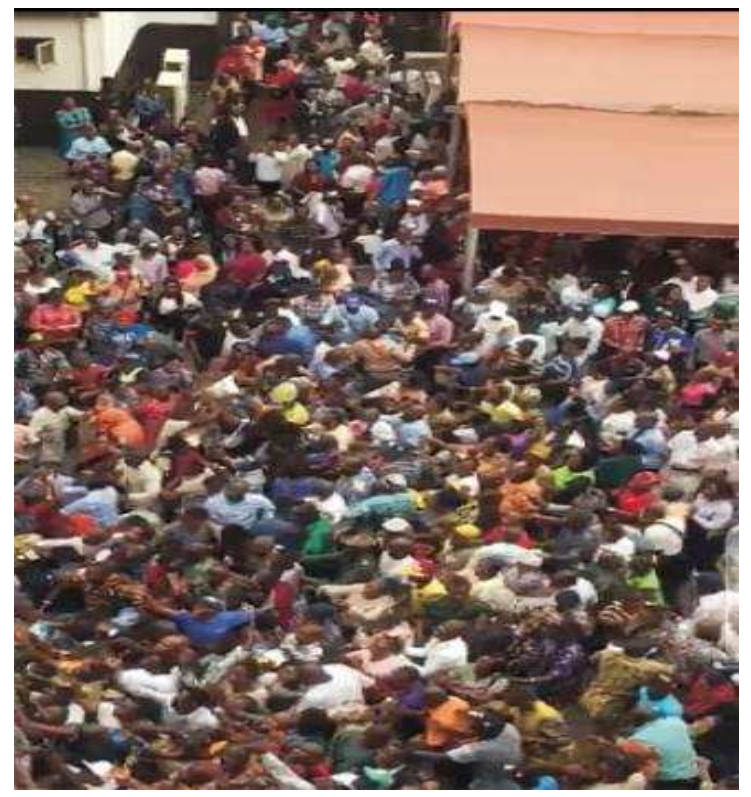

Figure2: A chaotic scene of people struggling and scrambling over the distribution of food distribution Source: King 's Global Health Institute April 23, 2020.

\section{Literature Review}

As COVID-19is taking many lives in its wake, putting many countries in disarray, it has brought an unexpected risk in all sectors. It has also triggered sudden economic disruption in all areas of human life(El-Erian,2020). The COVID-19has impacted approximately 200countries and two international conveyances (the Diamond Princess cruise ship in Yokohama, Japan, and the Holland American's M.S. Zaandam cruise ship)(From a regional perspective, confirmed cases were: 
North America(2,206,362cases and131,719 deaths); South America (with1,027,119cases and44,184deaths); Europe (with 1,014,373 while in fatality rate U.K., Italy, France has the highest with103,710death); West Pacific Countries(with China having the most affected cases with 84,638); India(with 266,598 cases and 1,074death); Bangladesh (with 68,504cases) and Indonesia (with 32,033)While the most affected countries in Africa are South Africa with 50,879cases and 1,080 deaths; Nigeria with 12,801cases and361death; Algeria with10,255cases and 715deaths; Ghana with 9,910 cases and Cameroon with 8,060 cases. The least affected are Lesotho with 4cases and 0 deaths; Seychelles with11cases and 0deaths; the Gambia with 28cases and 1death; Namibia with 31cases and Odeaths; Eritrea with 41cases and Odeaths (Piryani, Piryani, Bhandary,2020; African Developed Bank,2021a). The impact of COVID-19can be divided into different sections, such as the healthcare sector, economic sector, and social sector. (Haleem, Javaid, Vaishya, \& Deshmukh,2020).

Health care sector

The economic effect of influenza can be divided into direct and indirect, direct effect includes increased workload on health care workers, and increased healthcare expenditure (Verikios et al.,2011; McKibbin, \& Fernando, 2020). Hasanat et al. (2020) reveal that many lives have been lost to the COVID-19Pandemic. Even in well-resourced countries, the COVID-19pandemic has taxed healthcare systems beyond capacity, resulting in many people without access to life-saving measures (Essomba, Ciaffi, Etoundi \&Esiene,2020). The COVID-19pandemic affected patience with other kinds of diseases tends to get neglected, and there is also disruption in the medical supply chain (Haleem, Javaid, Vaishya,2020).

\section{Economic sector}

The effect of the virus on the economic sector is said to be both direct and indirect, an indirect effect which includes a reduction in labor supply, reduction in demand of goods, increase in absenteeism as a result of sick workers, and prophylactic absenteeism as a result of fear of contracting the illness (Verikios et al.2011). The socio-economic effect of the Pandemic has made people change the way they live their lives (Elavarasan et al.,2020). It has triggered a high risk of unemployment in different sectors of the economy, as Millions of people have lost their job (Walker et al., 2020). According to the last unemployment report released by the National Bureau Statistic(NBS), Nigeria ranks $21^{\text {st }}$ among 181 countries. It is further rated as the world's poverty capital, with 87million people living on less than $\$ 2$ a day threshold (CSEA,2020). Fornaro and 
Wolf 2020; El-Erian (2020) Used a simple model to reveal that Coronavirus triggered a negative supply shock and recommended that both monetary and fiscal policy is needed to prevent this negative supply shock. Furthermore, a general disruption of the supply chain resulting in firms and industries shutting down (Fornaro \&Wolf,2020); closure of borders has caused a drastic fall in demand for air travelers both in and out of the country, poor inflow and outflow of cash making the financial market to be unpredictable (Ozilil and Arun,2020) and slow in manufacturing of essential goods; as a result, lean operation of a business(Okediya,2020).

\section{Social Sector}

To control the spread of the Pandemic is without any social effect, which ranges from the measures taken such as: maintaining social distancing, wearing of face mask and face shield, travel ban, which all first started in Wuhan on January 23, 2020 (Chinazzi et al.,2020). Some of these measures seem like a "cultural shock" to many. Cultural shock is an inevitable experience, which is experienced in different ways(Patrick,2020). The impact of COVID-19on the Nigeria economy reveals that it is crippling social, economic, and religious activities and measures taken also impacted households in various ways, including loss of jobs, higher cost of goods, rationing of food items (Marshal, Nkwadochi \& Emmanuel 2020)

\section{RESEARCH METHODOLOGY}

\subsection{Area of the study}

The area of the study which is Anambra state and its capital Awka comprises of 21Local government area is located in the South East part of Nigeria. Awka both North and South Local government where the research was conducted has nineteen towns but, according to National Population Commission of Nigeria, (2016) Awka north and south has a total land area of 511.7 Kilometer square, with 399,300population. The scope of this study is limited to only household living in within both local government

\subsection{Research Approach}

A descriptive quantitative research method was employed for this study. According to Best and Kahn (1986), descriptive design is defined as conditions or relationship that exists, opinions that are held, processes that are going on, effects that are evident or trends that are developing. The purpose of descriptive research design is that it helps the researcher to collect factual information that describes the existing phenomenon. This survey aims to determine the source of the palliative measures they received, if at all. Moreover, what aspect of life was mostly affected. Pandey \& 
Pandey (2015) describe a research design as the framework of research method and techniques chosen by a researcher that guides collection and analysis. For analysis, the study adopted a descriptive research design using the questionnaire method and an open-ended questionnaire. The participant was drawn by randomly sampling techniques, including all households living within Anambra State, southeast Nigeria. The study sample includes 120 participants from different parts of the state, different geopolitical zones still living in the Awka metropolis in Nigeria.

\subsection{Participants:}

A total of 120 online Google questionnaires were delivered to the participants via social media platforms, out of which 100participant completed and submitted the survey; during analysis, the researcher excluded 4submitted because they were not properly filled; as a result, they were counted as rejected, and analysis was conducted on data from 96respondent:

\subsection{Research instrument, collection, and data analysis:}

The research instrument used for this study is an online questionnaire that included both structure and open-ended parts. The data collection instrument used for this study was selfdeveloped. At the same time, the questionnaires were developed based on previous researchers and relevant literature, and it was designed to suit the study participant. The questionnaire was made available and was distributed in google forms, using social media like WhatsApp, WeChat, and Facebook to circulate the information due to the lockdown and restriction of movement. According to Ofodum (2020). The questionnaire, including the open-ended question, was prepared to enable the respondent to give full details of their challenges during this Pandemic. The first five questions requested gender, age, zones, qualification, and what the respondent does for a living. Part two of the question focuses on eliciting the preventive measures, aspect affected, palliatives: the last part was for an open-ended question such as challenges, how covid impacted, and recommendations.

\subsection{Data Analysis}

The data collected were analyzed using the statistical package for social science(SPSS). The arithmetical mean, frequencies, standard deviation, and percentage of the answers gotten were calculated. While the open-ended questions were transcribed twice manually, the different themes were coded into a unique alphabet by bringing out themes from their responses. Secondly, a subtheme was listed, and its frequencies and proportions were found. 


\section{FINDINGS AND DISCUSSIONS}

The study's findings are summarized according to the research questions addressed in both openended and close-ended questionnaire format.

\section{Demographics of respondents.}

Gender of participants: Female 71.9\%(n:69) and Male 28.1\%(n:27); Age of the participant: 65.6\% (n:63) were between 26-30years, 27.1\% (n:26) were between 18-25years, 6.3\%(n:6) were between 31-35years and 1.0\% (n:1) was above 40years. Zones: 86.5(n:83) were from South East,5.2(n:5.2) were from South West, 3.1(n:3) were from South South, 3(n:3.1) were from North Central,2(n:1) were from North East. Qualifications:63.5\%(n:61) were bachelor, 11.5\% (n:11) were masters, 3.1\%(n:3) were secondary and 21.9\%(n:21) were others. Do for a living: $21.9 \%(\mathrm{n}: 21)$ were students, 20.8\%(n:20) were civil servants, $22.9 \%(\mathrm{n}: 22)$ do business,9.4\%(n:9) were unemployed and $25.0 \%$ (n:25) were others. From the above demographics it implies that females are more, $86.5 \%$ of the respondents are all from South East but lives in Awka where the research was carried,25.0\% are unemployed and $22.9 \%$ are either business men or women.

Research Question 1: What aspect of your life was affected?

Table 1: Aspect affected

\begin{tabular}{lllllll}
\hline & Health & Finance & Family & Social & Education & Psychology \\
Yes & 55.3 & 75.0 & 58.3 & 55.2 & 34.4 & 21.9 \\
No & 42.7 & 25.0 & 41.7 & 44.8 & 65.6 & 78.1 \\
\hline
\end{tabular}

Source: Field data, 2020

The emergence of the 2019 novel Coronavirus(2019-nCoV) in Wuhan, Hubei province China, has unprecedently affected different life and economic areas. Data collected through the questionnaire shows that:75.0\% $(\mathrm{n}=72)$ of the participant "finance" was mostly affected followed by "family" 58.3\% $(\mathrm{n}=56)$; "Health" 55.3\% $(\mathrm{n}=55)$; "Social" 55.2\% $(\mathrm{n}=53)$; "Education" $34.4 \%(\mathrm{n}=33)$; However, $21.9 \%(n=21)$ of the respondent stated that their "psychology" was the least affected. The above responses reveal that other aspects of life were also affected negatively but finance remains most crucial, as most people who were formally employed were discharged from their duties without paying salary, increasing the country's high unemployment rate(Adesanya,2020). Another kind of people whose finance was affected is the informal workers. It can also be evidenced that informal workers highly dominate the Nigerian economy (Awofeso\& Irabor,2020). This effect has 
practically changed people's pattern of life and consumption, making it difficult for even a family to eat 3threshold. (Nwokolo, Ogbuagu, \& Iwegbu, 2020).

Research Question 2: Preventive measures did you take to protect yourself?

Table 2: Preventive measures

\begin{tabular}{lllllll}
\hline & $\begin{array}{l}\text { Hand } \\
\text { washing }\end{array}$ & $\begin{array}{l}\text { Social } \\
\text { distancing }\end{array}$ & $\begin{array}{l}\text { Mask and } \\
\text { Facemask }\end{array}$ & $\begin{array}{l}\text { Avoid } \\
\text { of face }\end{array}$ & $\begin{array}{l}\text { Hand } \\
\text { Sanitizer }\end{array}$ & Gloves \\
Yes & 68.8 & 69.8 & 83.3 & 41.7 & 68.8 & 33.3 \\
No & 31.3 & 30.2 & 16.7 & 58.3 & 31.3 & 66.7 \\
\hline
\end{tabular}

Source: Field data,2020

According to WHO, preventive measures used in containing the COVID-19 Pandemic depend on each country's ability to control the spread(WHO,2020d). From the survey findings, $83.3 \%(n=80)$ of participants used "face mask," 69.8\% (n=67) indicated "social distancing," $68.8 \%(\mathrm{n}=66)$ reported "handwashing and use of hand sanitizer" as a means of protecting one selves.33.3(n=32) reported "hand gloves." Wearing face mask was the most common way the participant used to prevent themselves, which later became mandatory in almost all countries. Cartaud, Quesque, \& Coello, (2020). It is highly recommended that wearing a face mask against COVID-19results in a reduction of social distancing. All the preventive measures used by the respondent are also in line with the WHO directive and various Center for Disease Control (Iroulo, \& Boateng, 2020; WHO,2020).

Research Question 3: The Palliative gotten comes from where?

Table 1: Palliative

\begin{tabular}{lllll}
\hline & Church and Ngo & Family and Friends & Government & None of the above \\
Yes & 10 & 7 & 7 & 16 \\
No & 86 & 89 & 89 & 80 \\
\hline
\end{tabular}

Source: Field data,2020

Participants were also asked if they receive any palliative during this pandemic lockdown, and the survey reveals that $65.6 \%(n=63)$ admitted they did not receive any palliative from any organization. In comparison, $34.4 \%(n=33)$ mentioned they received some palliative. And when further asked those who got where it come from, $10.4 \%(\mathrm{n}=10)$ reveals they got palliative from the "Church and NGO," $7.3 \%(\mathrm{n}=7)$ reported that their palliative comes from family and friends and government; however, $16.7 \%(n=16)$ reported that the palliative they got come from other sources. Different Palliative measures which the federal government of Nigeria introduced to minimize the effect of the COVID-19Pandemic are said to be ineffective as the greater 
part of the participant from our finding received palliative from Churches and Non-governmental organizations. According to Olu, (2020), palliative giving by the Federal government of Nigeria are poorly coordinated and human right violation.

\section{Open-ended questionnaire}

For the researcher to better understand the challenges faced during the COVID-19Pandemic, all the 96participant participated actively in answering the open-ended questionnaire.

Theme and sub-themes responses.

\begin{tabular}{ll} 
Theme & Subtheme \\
\hline Challenges & Cost of commodity \\
& Delay \\
& Psychology \\
\hline Positive benefit Covid & Electricity \\
& New job \\
& Time with family \\
& New skills \\
\hline
\end{tabular}

\section{Challenges}

High cost of commodity: According to the participants, when there was no pandemic, the price of goods and services are relatively low, and one can afford two to three thresholds, but now the Pandemic has disrupted the supply while the demand is high resulting in sellers stockpiling and hiking the price of goods taking nose mask as an example.

A nose mask that used to be less than $\$ 0.2$ per packet is now being sold for $\$ 0.9$ per one depending on the location, and you expect me to buy at that price when I have not seen money to buy food. -Lizzy.

A shift in the price of goods and services will always make one shift in the pattern of living; as the price of goods rose beyond my imagination, I also need nothing but to make a U-turn. Simson.

In unity, Long, \& Khoi, (2020). assert that the COVID-19outbreak negatively influenced the price of goods and services through demand and supply of food in the market, and lockdown is also attributed to the highcost goods and services. Ataguba, (2020) The poor and vulnerable are being affected by the COVID19.

Epileptic electric supply: Most of the Participants reported that "during the lockdown, they hardly have electricity, making it difficult to stay indoors. 
I worry about not having enough money to buy foods, and when I buy, I won't see electricity to use and preserve the food. But the community always give me electricity bills to pay but have never enjoyed a $24 \mathrm{hrs} \mathrm{uninterrupted} \mathrm{power} \mathrm{Supply-Felix.}$

In congruence, Elavarasan et al. (2020) assert that the sudden change of plan and lifestyle has drastically increased the residential demand for electricity. One of the socio-economic problems a developing country faces is poverty, unemployment, and epileptic power supply (Adeniran, \& Sidiq, 2018).

Fear of the unknown: Some participants reveal that what they fear during the COVID-19lockdown was not just about contracting the virus but also the fear that hunger will deal with them if the lockdown continues.

I have never feared all my life the way I feared during the lockdown, I fear I might lose my job, contract the virus and the worst is hunger.-Eric

The fear of an unknown virus is also similar to the psychological effect of the reaction to biological and other terrorism threats, which also causes a high level of stress and panic (Hyams et al.,2002). As the Pandemic continues affecting people across the Globe, its estimated effect can be both short and long term. Many people would feel at risk at the onset of a pandemic, even if their actual risk of dying from the disease is low.

Psychological: One of the most affected people both physiologically and psychologically are those who suffers the Pandemic first hand. Sharma, (2020) Covid impact is limited to the financial aspect and psychological effects such as trauma, stigma attached to self-isolation, uncertainty, and death of loved ones. According to Akat, \& Karataş, (2020). Pandemic does not just have a devastating effect on peoples experiencing it but also the psychology of people's future.

COVID-19has spread across the Globe like a twinkle of an eye, causing both seen and unseen harm. I have never had reason to worry, feel depressed, fear, or have anxiety over something, not until the Covid was declared a pandemic. It made me worry so much that I might die or even lose my loved ones. - Lovett.

Delay of plans: One of the contingent measures taken by governments across the Globe is to close down all education systems (Ozer,2020) which impacted the world student population by 60\%, resulting in billions of students not learning in the schools but proceeding to provide an online and distance learning(Romer,2020). Delays in different aspects of once life goes with a popular saying that "Man proposes but God Disposes of". 
The Pandemic causes many delays in my life, it made me to cancel my wedding, my travel plans, and also I deferred my academics as I couldn't go back to the country where am studying. - Steph.

Being a civil servant, the Covid 19 made me at stay out home, delaying my other plan like saving money to buy a House-Mike.

\section{The positive effect of the Pandemic}

All over the world the Pandemic affected different areas of the economy, and but some sector and individual still had and is still having a positive effect. He et al., (2020) uses event study to empirically study the market performance and Chinese industries they found out that transportation, mining, electricity, and environment was adversely affected but the healthcare, manufacturing, education communication has benefited from the Covid impact. And this goes with a popular saying "Ndị n'ọchi ndị n'akwa" which means some are smiling and some crying. So from the finding of this research it reveals that $29.2 \%(\mathrm{n}-28)$ of the participant benefited from the COVID-19outbreak,67.7\%(n-65) did not benefit from the outbreak and the remaining 3.1\%(n-3) where neutral. But when further asked those who benefited how they revels:

Year "2020" I will tag it as my best year "since I graduated no job, no stable source of income but, during this period of Covid many companies which I have applied for job over the years called me to start job immediately-Edet.

If not Covid I won't be where I am today, I got my dream Job with the NHIS and will be travelling outside the Country-Divine.

Covid made me to realize I have a hidden talent and it was during this lockdown I met my husband -Genny.

I spent quality time with my family and also learnt how to use some new technology that I couldn't have learnt how to use it. -Isac

I have never had a quality time with my family due to the kind of job I do but, covid made it possible. -Maria

\section{Conclusion}

This paper discussed the Covid -19 impact and how palliative care provided was used or distributed, with the emergence of COVID-19caused by the SARS-CoV-2 virus has drastically changed the face of the earth; people's daily lifestyles changed. Different measures that were put in place to mitigate the effect are without any harmful dilemma. In recognizing the difficulty associated with the preventive measures, the Federal Government promised palliative measures in conditional cash transfer. This research found out that the aspect affected during the lockdown was the finance, and the palliative, which was meant to cushion the effect, was hoarded, hijacked, and ineffectively 
distributed. Also, challenges associated with lockdown include epileptic power supply, fear of the unknown, overnight change of plan. In the face of a Pandemic or outbreak, we all need to come "together and fight." Also the vulnerable, the poor and the informal worker should be considered first because they are usually affected the most.

\section{Recommendation}

As the future is unknown and based on the findings of this study, the following recommendations are made:

\section{For the Government}

1. It is recommended that countries whose health care systems are yet to attain the standard should endeavor to fix it rather than building new ones and never maintain the already existing facilities, which is one of the major problems in Nigeria.

2. Government should set up a committee that can regulate the commodity market as people use in the face of crises to extort money by raising the price of a commodity.

3. Lay down rules and regulations should be given and followed up on how any palliative care can be distributed.

4. Palliative should be an essential part of any response to a humanitarian crisis.

5. Salaries of workers should be always being paid ahead.

6. Recommendation of hand washing requires access to basic amenities such as water, electricity being made available and accessible.

7. Giving and assisting the small and medium scale enterprises, the Pandemic made the government and individuals know we can provide things independently rather than solely relying on other countries for importation.

8. The fiscal and monetary policy provided by the government should be used for the purpose and its purpose alone.

9. Regulation on how one can stand on his knees after the Pandemic should be drafted

10. The outbreak of the virus is also an avenue for the government to strengthens its healthcare system.

\section{For the family}

1. One source of income is not enough to hold or sustain an individual.

2. It also calls for rethinking in all sectors.

3. Encourage personal hygiene. 


\section{Declaration of competing interest}

I, declare that I have no known competing financial interest.

\section{References}

Abara, E. (2020). Updated: List of all Companies and Billionaires that have contributed to COVID-19Relief Fund. Naira metrics, Available:https://nairametrics.com/2020/04/18/list-of-all-companiesandbillionaires-that-have-contributed-to-covid-19-relief-fund/ Accessed June 232020.

Adeniran, A. O., \& Sidiq, B. O. (2018). Economic recession and the way-out: Nigeria as case study. Global Journal of Human Social Science, 18(1), 181-192.

Adesanya, O. A. (2020). Government preparedness and response towards COVID-19outbreak in Nigeria: A retrospective analysis of the last 6 months. Journal of Global Health, 10(2).

African Development Bank (2021a, February 7). Weekly Data Flash on COVID $\square 19$ in Africa1: The situation as of Sunday. Statistics Department (ECST), African Development Bank, Abidjan.

Akat, M., \& Karataş, K. (2020). Psychological Effects of COVID-19Pandemic on Society and Its Reflections on Education. Electronic Turkish Studies, 15(4).

Ataguba, J. E. (2020). COVID-19 Pandemic, a war to be won: understanding its economic implications for Africa. Appl Health Econ Health Policy 18, 325-328 http://doi.org/10.1007/s40258-0200580-x.

Ather, A., Patel, B., Ruparel, N. B., Diogenes, A., \& Hargreaves, K. M. (2020). Coronavirus disease 19 (COVID-19): implications for clinical dental care. Journal of endodontics, 46(5), 584-595.

Awofeso, O., \& Irabor, P. A. (2020). Assessment of government response to socioeconomic impact of COVID-19pandemic in Nigeria. Journal of Social and Political Sciences, 3(3).

Bankert, E. A., \& Amdur, R. J. (2006). Institutional review board: Management and function. Jones \& Bartlett Learning.

Best, J. W., \& Kahn, J. V. (2016). Research in education. Pearson Education India.

Brown, C., Arkell, P., \& Rokadiya, S. (2015). Ebola virus disease: the 'Black Swan 'in West Africa. Tropical Doctor, 45(1), 2-5.

Business Day Newspaper Report. (April 12, 2020a). Controversial palliatives tear Nigerians apart. https://businessday.ng/lead-story/article/controversial-palliatives-tear-nigerians apart/ Retrieved on May 23, 2020.

Business Day Newspaper Report. (April,19 2020). Lamentation still trails Lagos, FG'Spalliativepackageasmiddlemenhijackprogramme.http://www.pressreader.com/nigeria/business /business-day-nigeria/20200419/281745566523897.Retrived on May 21,2020.

Cartaud, A., Quesque, F., \& Coello, Y. (2020). Wearing a face mask against Covid-19 results in a reduction of social distancing. Plos one, 15(12), e0243023.

Cassidy,J.(2020)An Economic-History Lesson for Dealing with the Coronavirus, New Yorker (March 18 2020) [available athttps://www.newyorker.com/news/our-columnists/an-economic-history-lessonfor-dealingwith-the-coronavirus, accessed on March 312020. 
CDC, (2020a). Centers for Disease Control and Prevention, National Center for immunization and Respiratory Diseases(NCIRD).

Centre for the Study of Economies of Africa (CSEA) (2020). The implication of Covid'19 on the Nigerian Economy. Retrieved April 13, 2020, from http://cseaafrica.org/the-implication-of-covid19-on-thenigerian-economy/.

Chan, J. F. W., Yuan, S., Kok, K. H., To, K. K. W., Chu, H., Yang, J., ... \& Yuen, K. Y. (2020). A familial cluster of pneumonia associated with the 2019 novel coronavirus indicating person-to-person transmission: a study of a family cluster. The lancet, 395(10223), 514-523.

Chen, J., Wang, X., Zhang, S., Lin, B., Wu, X.,Wang, Y., . . Xie, Y. (2020a). Characteristics of acute pulmonary embolism in patients with COVID-19associated pneumonia from the city of Wuhan. Clinical and Applied Thrombosis/Hemostasis, 26, 1-8. doi:10.1177/1076029620936772.

China Xinhua net. (2020). Xi Jinping's "2:23" Important Speech: The "Episode" Program Aiming for Victory. Retrieved from http://www.xinhuanet.com/politics/2020-02/25/c_1125625675. htm,0223/2020-03-11.

Chinazzi, M., Davis, J. T., Ajelli, M., Gioannini, C., Litvinova, M., Merler, S., ... \& Vespignani, A. (2020). The effect of travel restrictions on the spread of the 2019 novel coronavirus (COVID-19) outbreak. Science, 368(6489), 395-400.

CNBC African News Report (2020). COVID-19: Nigeria extends lockdown by two weeks in Lagos, Abuja \& Ogun States. https://www.cnbcafrica.com/coronavirus/2020/04/13/COVID-19-nigeria-extendslockdown-by-two-weeks-in-lagosabuja-ogun-states/ Retrieved on May 22, 2020.

CODE, Q. (2020). COVID-19and Sustainable Development Goals (SDGs). Sustainable Development.

Elavarasan, R. M., Shafiullah, G. M., Raju, K., Mudgal, V., Arif, M. T., Jamal, T., ... \& Subramaniam, U. (2020). COVID-19: Impact analysis and recommendations for power sector operation. Applied energy, 279, 115739 .

El-Erian, M. (2020). The coming coronavirus recession and the uncharted territory beyond. Foreign Affairs, Media Report. Available at: https://www. Foreign affairs. com/articles/2020-03-17/comingcoronavirus-recession.

Eranga, I. O. E. (2020). COVID-19Pandemic in Nigeria: Palliative measures and the politics of vulnerability. International Journal of maternal and child health and AIDS, 9(2), 220.

Essomba, M. J. N., Ciaffi, L., Etoundi, P. O., \& Esiene, A. (2020). Palliative and end-of-life care in COVID19management in sub-Saharan Africa: a matter of concern. The Pan African Medical Journal, 35(Suppl 2).

Estrada, M. A.R, Park, D., Koutronas, E., Khan, A., \& Tahir, M. (2020). The impact of infectious and contagious diseases and its impact on the economic performance: The case of Wuhan, China. China (January 29, 2020).

Fernandes, N. (2020). Economic effects of coronavirus outbreak (COVID-19) on the world economy. Available at SSRN 3557504. 
Fornaro, L., \& Wolf, M. (2020). COVID-19Coronavirus and macroeconomic policy.

Gilbert, M., Pullano, G., Pinotti, F., Valdano, E., Poletto, C., Boëlle, P. Y., ... \& Gutierrez, B. (2020). Preparedness and vulnerability of African countries against importations of COVID-19: a modelling study. The Lancet, 395(10227), 871-877.

Haleem, A., Javaid, M., \& Vaishya, R. (2020). Effects of COVID-19Pandemic in daily life. Current medicine research and practice, $10(2), 78$.

Haleem, A., Javaid, M., Vaishya, R., \& Deshmukh, S. G. (2020). Areas of academic research with the impact of COVID-19. The American journal of emergency medicine, 38(7), 1524-1526.

Hasanat, M. W., Hoque, A., Shikha, F. A., Anwar, M., Hamid, A. B. A., \& Tat, H. H. (2020). The impact of Coronavirus (COVID-19) on e-business in Malaysia. Asian Journal of Multidisciplinary Studies, 3(1), 85-90.

Hellewell, J., Abbott, S., Gimma, A., Bosse, N. I., Jarvis, C. I., Russell, T. W., ... \& Eggo, R. M. (2020). Feasibility of controlling COVID-19outbreaks by isolation of cases and contacts. The Lancet Global Health, 8(4), e488-e496.

Huang, C., Wang, Y., Li, X., Ren, L., Zhao, J., Hu, Y., ... \& Xu, J. (2020). XiaoyingGu. Zhen shun Cheng, Ting Yu, Jian Xia, Yuan Wei, Wenjuan Wu, Xuelei Xie, Wen Yin, Hui Li, Min Liu, Yan Xiao, Hong Gao, Li Guo, JungangXie, Guangfa Wang, Rongmeng Jiang, Zhancheng Gao, Qi Jin, Jianwei Wang, Bin Cao. Clinical features of patients infected with 2019 novel coronavirus in Wuhan, China. Lancet,2020; S0140-6736(20)30183-5. https:// doi.org/10.1016/S0140-6736(20)30154-9 PMID: $31986261 \mathrm{Jan} 24$.

Iroulo, L. C., \& Boateng, O. (2020). African States Must Localize Coronavirus Response. (GIGA Focus Afrika, 3). Hamburg: GIGA German Institute of Global and Area Studies.

Johns Hopkins Coronavirus Resource Center. (2020). COVID-19case tracker. Accessed: April 252020. https://coronavirus.jhu.edu.

Kalu B. (2020). COVID-19in Nigeria: a disease of hunger. The Lancet. Respiratory medicine, 8(6), 556557. https://doi.org/10.1016/S2213-2600(20)30220-4.

King's Global Health Institute, (2020). 'Chaotic' distribution of COVID-19pandemic lockdown palliative in Abuja, Nigeria.http://www. Kcl.ac.uk/kghi/news/Peter-Nigeria. Retrieved May 23,2020.

Koshle, H., Kaur, R., \& Basista, R. (2020). Breakdown of business and workers in India: impact of corona virus. Available at SSRN 3557544.

Long, N. N., \& Khoi, B. H. (2020). An empirical study about the intention to hoard food during COVID-19 pandemic. Eurasia Journal of Mathematics, Science and Technology Education, 16(7), em1857.

Lovelace, B. J. (2020, August 21). WHO warns coronavirus vaccine alone won't end Pandemic: 'We cannot go back to the way things were'. Retrieved from https://www.cnbc.com/2020/08/21/who-warnsacoronavirus-vaccine-alone-will-not-end-pandemichtml. 
Marshal, I., Nkwadochi, K. C., \& Emmanuel, A. (2020). COVID-19pandemic, global trade wars and impact on the Nigeria economy. Academic Journal of Current Research, 7(5), 71-82.

McKibbin, W. J., \& Fernando, R. (2020). The global macroeconomic impacts of COVID-19: Seven scenarios. Asian Economic Papers, 20(2), 1-30.

NCDC, (2020a). Nigeria Center for Disease Control an update of COVID-19outbreak in Nigeria. NCDC COVID-19Update.Retrived on May 11,2020.

Nkengasong, J. N., \& Mankoula, W. (2020). Looming threat of COVID-19 infection in Africa: act collectively, and fast. The Lancet, 395(10227), 841-842.

Nwokolo, C. I., Ogbuagu, M. I., \& Iwegbu, O. (2020). Impact of Coronavirus Pandemic on the Global Economy: Demand and Supply Shock.

Obiakor, T., \& Adeniran, A. P. (2020). Covid-19: Impending Situation Threatens to Deepen Nigeria's Education Crisis.

Ojogiwa, O. T., \& Akinola, A. (2020). The Impact of Government Responses to COVID-19on the Urban Poor in Lagos State, Nigeria. African Journal of Governance \& Development, 9(1.1), 367-381.

Okediya, P. (2020). Impact of COVID-19in the Nigerian Commercial Community: A Roadmap for Agencies. Available at SSRN 3547639.

Oruonye, E. D., \& Ahmed, Y. M. (2020). An appraisal of the potential impacts of COVID-19on tourism in Nigeria. Journal of Economics and Technology Research, 1(1), 32-41.

Özer, M. (2020). Educational policy actions by the Ministry of National Education in the times of COVID19Pandemic in Turkey. Kastamonu Educational Journal, 28(3), 1124-1129.

Ozili, P. K., \& Arun, T. (2020). Spillover of COVID-19: impact on the Global Economy. Available at SSRN 3562570 .

Pandey, P., \& Pandey, M. M. (ed.). (2015). Research Methodology: Tools and techniques (5th ed.). Romania, European union. Bridge center.

Patrick, O. B. (2020). Effects and Remedies of Culture Shock on Higher Education Students in China. European Journal of Research and Reflection in Educational Sciences Vol, 8(12).

Peter Ezeah, (2020) 'Chaotic' distribution of COVID-19pandemic lockdown palliatives in Abuja Nigeria. Retrieved on September 15,2020 from http://healthasset.org/chaotic-distribution-of-codvi-19pandemic-palliative-in-abuja-nigeria/.

Piryani RM, Piryani S, Bhandary S. Deaths due to COVID-19in Affected Countries' Infectiology. 2020; 3(1): 14-17

Qiu, W., Rutherford, S., Mao, A., \& Chu, C. (2017). The Pandemic and its impacts. Health, culture and society, 9, 1-11.

Riou, J., \& Althaus, C. L. (2020). Pattern of early human-to-human transmission of Wuhan 2019 novel coronavirus (2019-nCoV), December 2019 to January 2020. Eurosurveillance, 25(4), 2000058. 
Sá, M. J., \& Serpa, S. (2020). The global crisis brought about by SARS-CoV-2 and its impacts on education: An overview of the Portuguese panorama. Sci Insigt Edu Front, 5(2), 525-530.

Salisu, A. A., Sikiru, A. A., \& Vo, X. V. (2020). Pandemics and the emerging stock markets. Borsa Istanbul Review, 20, S40-S48.

Sharma, N. (2020). Traumatic Skepticism of COVID 19. International Journal of Multidisciplinary Perspectives in Higher Education, 5(1), 84-88.

Tacoli, C. (2017). Food (in) security in rapidly urbanizing, low-income contexts. International journal of environmental research and public health, 14(12), 1554.

The Nigerian Guardian Newspaper Report. (2020a). F.G.'s COVID-19palliatives: Why Nigerians are not feeling the impact. https://guardian.ng/saturday-magazine/fgs-covid-19- palliatives-why-nigeriansare-not-feeling-the-impact/ Retrieved September 14, 2020.

The Nigerian Guardian Newspaper Report. (2020b). The Guardian Newspaper Report. (2020). 'Equitable distribution of palliative measures will check citizens' unrest'. https://guardian.ng/news/equitabledistribution-of-palliative-measures-willcheck-citizens-unrest/ Retrieved on May 22, 2020.

Topcu, M., \& Gulal, O. S. (2020). The impact of COVID-19on emerging stock markets. Finance Research Letters, 36, 101691.

Verikios, G., Sullivan, M., Stojanovski, P., Giesecke, J. A., \& Woo, G. (2011). The global economic effects of pandemic influenza. Centre of Policy Studies (CoPS).

Walker, P. G., Whittaker, C., Watson, O. J., Baguelin, M., Winskill, P., Hamlet, A., \& Thompson, H. (2020). The impact of COVID-19 and strategies for mitigation and suppression in low-and middle-income countries. Science. Vol. 369, Issue 6502, pp. 413-422.

WHO. Novel coronavirus - Japan (ex-China). Jan 17, 2020. http://www.who.int/csr/don/17-january-2020novel-coronavirusjapan-ex-china/en/ (accessed Jan 19, 2020).

WHO. Novel coronavirus - Republic of Korea (ex-China). Jan 21, 2020. http://www.who.int/csr/don/21january-2020-novelcoronavirus-republic-of-korea-ex-china/en/ (accessed Jan 23, 2020).

WHO. Novel coronavirus - Thailand (ex-China). Jan 14, 2020. http://www.who.int/csr/don/14-january2020-novel-coronavirusthailand/en/ (accessed Jan 19,2020).

World Health Organization. (2020a). Pneumonia of unknown cause - China. Geneva: WHO; 2020. Available from: https://www.who.int/csr/don/05-january-2020-pneumonia-of-unkown-causechina/en/.

World Health Organization. (2020c). Novel Coronavirus (2019-nCoV) situation report 9. Geneva: WHO. Available from: https://www.who.int/docs/default-source/ coronavirus/situation-reports/20200129sitrep-9-ncov-v2. pdf? sfvrsn=e2c8915_2.

World Health Organization (2020d) Regional Office for Africa (February 31, 2020). WHO ramps up preparedness for novel coronavirus in the African region. 
World Health Organization. (2020e). Naming the coronavirus disease (COVID-19) and the virus that causes it. Retrieved on April 222020 from https://bit.ly/2KHu29A

World Health Organization(2020f). There is a current outbreak of Coronavirus(Covid-19) diseases. Retrieved from:http//www.who.int/health-topics/coronavirus\#tab=tab-1.

World Health Organization(2020g) WHO Timeline - COVID-19. 2020. Available from: https://www.who.int/news-room/detail/27-04-2020-who-timeline-covid-19 Accessed: August 12 2020 .

World Health Organization. (2019). World health statistics 2019: monitoring health for the SDGs, sustainable development goals. World Health Organization.

Yan, Z. (2020). Unprecedented Pandemic, unprecedented shift, and unprecedented opportunity. Human Behavior and Emerging Technologies.

Zeren, F., \& HIZARCI, A. (2020). The impact of COVID-19Coronavirus on stock markets: evidence from selected countries. Muhasebe ve Finans İncelemeleri Dergisi, 3(1), 78-84.

Zhou P, Yang X-L, Wang X-G, Hu B, Zhang L, Zhang W, et al., (2020). Discovery of a novel coronavirus associated with the recent pneumonia outbreak in humans and its potential bat origin. bioRxiv. 2020; 10.1101/2020.01.22.914952.Availablefrom:https://www.biorxiv.org/content/early/2020/01/23/2020 .01 .22 .914952 . 